\title{
Evaluasi Penyaluran Dana Ekonomi Bergulir Untuk Memberdayakan Masyarakat di Kelurahan Padangmatinggi
}

\author{
Nurharisyah Hasibuan \\ Fakultas Dakwah dan Ilmu Komunikasi IAIN Padangsidimpuan \\ (nurharisyahhasibuan@gmail.com)
}

\begin{abstract}
Distribution of revolving economic funds is carried out by means of savings and loans, which are given directly to the poor for business development. The results showed that the distribution of economic funds revolving in Padangmatinggi village was carried out by various selections by the BKM team and grouping all poor people who received revolving economic funds. Meanwhile, the evaluation of revolving economic fund distribution in the Padangmatinggi village is said to be not going well. This condition is seen from the four performance indicators of the PNPM team (survey, distribution, supervision and evaluation), some are not working well, namely supervision. This is evidenced by the existence of people who still have not paid the revolving economic fund loans in the Padangmatinggi village.
\end{abstract}

Keywords: Empowerment, Revolving Fund

\begin{abstract}
Abstrak
Penyaluran dana ekonomi bergulir dilakukan dengan cara simpan pinjam, yang diberikan langsung kepada masyarakat miskin untuk pengembangan usaha. Hasil penelitian menunjukkan bahwa penyaluran dana ekonomi bergulir di kelurahan Padangmatinggi dilakukan dengan berbagai seleksi oleh tim BKM dan mengelompokkan semua masyarakat miskin yang menerima bantuan dana ekonomi bergulir. Sementara itu, evaluasi penyaluran dana ekonomi bergulir di kelurahan Padangmatinggi dikatakan kurang berjalan dengan baik. Kondisi itu dilihat dari empat indikator kinerja tim PNPM (survei, penyaluran, pengawasan dan evaluasi), ada yang tidak berjalan dengan baik yaitu tentang pengawasan. Hal ini dibuktikan dengan adanya masyarakat yang masih belum membayar pinjaman dana ekonomi bergulir di kelurahan Padangmatinggi.
\end{abstract}

Kata Kunci : Pemberdayaan, Dana Bergulir 


\section{A. Pendahuluan}

Pemberdayaan adalah upaya untuk memberikan kesempatan dan kemampuan pada kelompok masyarakat untuk berpartisipasi, bernegoisasi, mempengaruhi dan mengendalikan kelembagaan masyarakat secara bertanggung jawab demi perbaikan kehidupan. ${ }^{1}{ }^{2}$ Hurairah, 2011) Pemberdayaan ekonomi, masalah kemiskinan menjadi identik dengan masyarakat Indonesia. Pemecahannya adalah tanggung jawab masyarakat itu sendiri yang selama ini selalu terpinggirkan. Karena itu, Pemerintah perlu memberdayakan masyarakat baik dari agama, intelektual dan ekonomi. Namun, peneliti lebih terfokus untuk membahas masalah pemberdayaan ekonomi.

Pemberdayaan sangat penting bagi individu maupun kelompok masyarakat yang kurang beruntung, apalagi dari segi ekonomi. Pemberdayaan berarti upaya partisipasi bersama secara terprogram, terarah, terorganisir untuk meningkatkan harkat dan martabat golongan masyarakat yang sedang dalam kondisi kurang sejahtera sampai miskin, sehingga mereka dapat melepaskan diri dari perangkap kemiskinan dan keterbelakangan.

Dalam rangka merealisasikan upaya peningkatan harkat dan martabat masyarakat tersebut pada tahun 2007 Pemerintah membuat program yang bernama PNPM. Program PNPM dinyatakan dengan Keputusan Presiden No 7 Tahun 2005 tentang rencana pembangunan jangka menengah nasional. Melalui program tersebut dirumuskan kembali mekanisme upaya pemberdayaan perekonomian masyarakat yang melibatkan unsur masyarakat mulai dari tahap perencanaan, pelaksanaan hingga pemantauan dan evaluasi. Program Nasional Pemberdayaan Masyarakat (PNPM) adalah program nasional yang menjadi kerangka dasar dan acuan pelaksanaan program-program pengentasan kemiskinan berbasis pemberdayaan masyarakat.

Tujuan Umum PNPM adalah meningkatnya kesejahteraan dan kesempatan kerja masyarakat miskin dengan mendorong kemandirian dalam pengambilan keputusan dan pengelolaan pembangunan. Salah satu cara untuk meningkatkan kesejahteraan masyarakat adalah dengan memberi bantuan dana bergulir yang akan digunakan masyarakat untuk mengembangkan usaha mereka. Penyaluran dana bergulir ini mensyaratkan masyarakat membentuk sebuah Kelompok Swadaya Masyarakat (KSM).

Program pengentasan kemiskinan melalui penyaluran dana bergulir merupakan bentuk pemberian pinjaman jangka pendek kepada pemilik usaha mikro dan kecil anggota KSM. Dana bergulir ini diharapkan dapat membantu peningkatan kinerja usaha sehingga dapat menghasilkan manfaat kepada pemiliknya. Sedangkan, penilaian kinerja dana bergulir ini akan terlihat dari perbandingan kinerja keuangan sebelum dan sesudah mendapat bantuan dana bergulir.

Di Kelurahan Padangmatinggi PNPM memberi bantuan dana bergulir pertama kali pada tahun 2008 dengan jumlah dana sebesar Rp 40.000.000,-. Dana ini digulirkan kepada masyarakat dengan sistem kelompok. Pada tahun 2008, setiap individu dalam kelompok dapat meminjam sebesar Rp 500.000,- dan pada tahun 2013 meningkat menjadi Rp 1.000.000,-. Setiap individu kelompok bisa mendirikan usaha, seperti Home industry, usaha kerupuk sambal dan lain sebagainya. Hasil dari penjualan dikumpul untuk mencicil pinjaman dana bergulir. Bentuk pengembalian pinjaman tersebut di cicil 1 kali 1 bulan selama 10 bulan.

1 Abu Huraerah, Pengorganisasian dan Pengembangan Masyarakat, (Bandung: Humaniora, 2011), hlm.96

${ }^{2}$ Abu Hurairah, Pengorganisasian Dan Pengembangan Masyarakat (Bandung: Humaniora, 2011). 
Dari tahun 2007-2014 ada 30 kelompok yang meminjam dana ekonomi bergulir untuk mengembangkan usahanya yang terdiri dari Lk. I, II, dan III. Namun dari 50 kelompok tersebut tidak semua kelompok maupun individu yang membayar cicilan sesuai dengan waktu, janji dan jumlah yang telah ditetapkan. Kelompok yang meminjam pada tahun 2008 ada 8 kelompok, yang terdiri dari 4,5, 6, atau 7 orang. Setiap orang individu dapat meminjam sebesar Rp 500.000,- jika kelompok tersebut terdiri dari 6 orang maka satu kelompok tersebut mendapat pinjaman dana ekonomi bergulir sebesar Rp 3.000.000,-. Pinjaman ini bisa dicicil per orang ataupun per kelompok. Karena dana ekonomi bergulir yang dipinjamkan kepada masyarakat bukan merupakan modal awal dalam membuka usaha melainkan modal penambah bagi tiap orang atau masyarakat dalam mengembangkan usahanya.

Program ini terus meningkat sampai tahun 2014, dan di tahun 2013 kelurahan Padangmatinggi mendapat dana reword sebesar Rp.100.000.000,- karena keberhasilan pengembalian pinjaman dana ekonomi bergulir pada tahun sebelumnya. Dana reword ini di salurkan kepada masyarakat miskin sebanyak 8 kelompok dengan masing-masing individu mendapat pinjaman sebesar Rp.2.000.000,-. Namun dari 8 kelompok tersebut tidak semua kelompok maupun individu yang membayar cicilan sesuai dengan waktu,janji dan jumlah yang ditetapkan. Sehingga pada tahun 2014 dihitung jumlah dana ekonomi bergulir yang belum dikembalikan masyarakat secara keseluruhan berjumlah Rp 60.000.000,-. Sehingga sisa dana ekonomi bergulir yang tinggal pada UPK hanya sebesar Rp. 40.000.000,-. Karena kendala penyicilan atau pengembalian pinjaman masyarakat kepada UPK ataupun PNPM tidak berjalan dengan lancar, mengakibatkan dana ekonomi bergulir mengalami kemunduran ataupun kekurangan dana, sehingga pihak PNPM berinisiatif memberhentikan penyaluran dana ekonomi bergulir kepada masyarakat.

Oleh karena itu, program dana ekonomi bergulir ini perlu diadakan evaluasi untuk melihat peningkatan kesejahteraan masyarakat sebelum dan sesudah menerima bantuan modal dari dana bergulir. Evaluasi adalah melakukan penilaian atas segala sesuatu yang diamati berdasarkan hasil perbandingan atau pengukuran yang dilakukan. Tahap evaluasi merupakan tahap yang penting dalam pemberdayaan masyarakat sebab tahap ini menjadi tolak ukur keberhasilan dan keberlanjutan program yang telah dibuat.

\section{B. Landasan Teori}

\section{Pengertian Evaluasi}

Evaluasi merupakan istilah serapan dari dalam Bahasa inggris yaitu "evaluation". Evaluation sendiri berasal dari akar kata "value" yng berarti nilai. Selanjutnya dari kata nilai terbentuklah kata "penilaian". Kata "evaluasi", dalam kehidupan sehari hari sering di artikan sebagai padanan istilah dari "penilaian", suatu tindakan pengambilan keputusan untuk menilai suatu objek, keadaan, peristiwa atau kegiatan tertentu yang sedang dialami. Ada beberapa pendapat para ahli mengenai pengertian evaluasi, antara lain. Menurut Suharsimi Arikunto dalam buku Pemberdayaan Masyarakat, evaluasi berasal dari kata Bahasa Inggris yaitu evaluation yang diterjemahkan dalam Bahasa Indonesia berarti evaluasi atau penilaian, yang artinya kegiatan yang membandingkan sesuatu hal dengan satuan ukuran tertentu. Seepersad dan Henderson dalam buku Pemberdayaan Masyarakat, mengartikan evaluasi sebagai kegiatan sistematis yang 
dimaksudkan untuk melakukan pengukuran dan penilaian terhadap suatu objek berdasarkan pedoman yang telah ada. ${ }^{3}$

Evaluasi program adalah evaluasi yang dilakukan untuk mengkaji kembali draft/usulan program yang sudah dirumuskan sebelum program itu dilaksanakan. Tentang evaluasi program ini, secara khusus, Rossi dkk. Sangat menekankan petingnya kegiatan evaluasi terhadap:

a. Siapa (kelompok) penerima manfaat program, dimana lokasinya, dan bagaimana spesifikasi (kekhususan) kelompok penerima manfat program tersebut;

b. Apa metode yang terbaik ayng akan diterapkan, demi tercapainya tujuan yang diinginkan;

c. Apakah program tersebut benar-benar konsisten dengan tujuan yang diinginkan;

d. Seberapa jauh peluang keberhasilan program yang akan dilaksanakan itu.

Tujuan evaluasi menurut Nanang Fatah adalah sebagai berikut:

a. Untuk memproleh pertimbangan akhir suatu priode kerja, tentang apa yang belum di capai dan yang sudah di capai.

b. Untuk menjamin cara kerja yang efektif dan efesien.

c. Untuk memperoleh fakta tentang kesulitan dan hambatan. ${ }^{4}$

\section{Program Nasional Pemberdayaan Masyarakat (PNPM)}

PNPM adalah program nasional yang menjadi kerangka dasar dan acuan pelaksanaan program-program pengentesan kemiskinan berbasis pemberdayaan masyarakat. Tujuan Umum PNPM Mandiri adalah meningkatnya kesejahteraan dan kesempatan kerja masyarakat miskin denga mendorong kemandirian dalam pengambilan keputusan dan pengelolaan pembangunan. Salah satu cara untuk meningkatkan kesejateraan masyarakat adalah dengan memberi bantuan dana bergulir yang akan digunakan masyarakat untuk mengembangkan usaha mereka.

Penyaluran dana bergulir ini mensyaratkan masyarakat membentuk suatu kelompok swadaya masyarakat (KSM). Penyaluran dana bergulir merupakan bentuk pemberian pinjaman kepada setiap kelompok. Dana bergulir ini dapat membantu peningkatan kinerja usaha sehingga dapat menghasilkan manfaat kepada setiap kelompok. Sebagai bagian bantuan yang berbentuk pinjaman, maka penilaian kinerja pengelolaannya dapat di lakukan menggunakan indikator-indikator dalam menejemen keuangan. Penilain kerja usaha mikro dan kecil dalam memanfaatkan dana bergulir dapat diwakili oleh rasio likuiditas dan profitabilitas.

Rasio likuiditas merupakan indikator yang penting untuk melihat pengelolaan bergulir karena dana tersebut merupakan bagian dari hutang jangka pendek yang harus di kembalikan dalam jagka waktu kurang dari satu tahun. Rasio profitabilitas akan menunjukkan kemampuan pemilik usaha mikro dan usaha kecil untuk mengelola investasi yang di biyayai dari dana bergulir, menunjukkan hasil akhir dari sejumlah kebijakan dan keputusan yang dilakukan oleh pemilik atau pengelolah sumber keuangan dana bergulir, serta juga akan menunjukkan kombinasi efek likuiditas manajemen.

Penilaian kinerja dana bergulir ini akan terlihat dari perbandingan kinerja sebelum dan sesudah mendapat bantuan dana bergulir sebelum dan sesudah dana bergulir. Pada tahun 2007 pemerintah Indonesia kembali meluncurkan program pengentasan

3 Totok Mardikanto dan Poerwoko Soebianto, Pemberdayaan Masyarakat Dalam Perspektif Kebijakan Publik, (Bandung: Alfabeta, 2013), hlm. 264-265

${ }^{4}$ Totok Mardikanto dan Poerwoko Soebianto, Pemberdayaan Masyarakat Dalam Perspektif Kebijakan Publik, (Bandung: Alfabeta, 2013), hlm. 264-265 
kemiskinan yang bernamaPNPM. Program ini memberikan pokus pada upaya pementasan kemiskinan dengan melibatkan unsur masyarakat, mulai dari tahap perencanaan, pelaksanaan, hingga pemantauan dan efaluasi. Ruang lingkup PNPM pada prinsipnya terbuka bagi semua kegiatan masyarakat yang meliputi:

a. Penyediaan dan perbaikan prasarana/ sarana lingkungan pemukiman, social, dan ekonomi.

b. Penyediaan sumber daya keuangan melalui dana bergulir.

c. Kegiatan terkait peningkatan kualitas sumber daya manusia.

d. Pelatihan keterampilan usaha.

Dalam penyaluran dana ini harus di lakukan evaluasi terhadap outcome PNPM dalam setiap pinjaman maupun penyaluran dana bergulir yang di berikan kepada masyarakat. Kinerja dana bergulir PNPM dapat di ukur melalui rasio keuangan likuiditas dan profitabilitas. Rasio ini dipilih karena pada penilitian ini yang menjadi sampel usaha kecil yang memiliki modal kecil, aktiva yang kecil, dan laba yang kecil. Berdasarkan hal tersebut, maka rasio yang cocok mengukur kinerja keuangan adalah rasio likuiditas dan profitabilitas. Sementara itu kinerja dana bergulir ini untuk meningkatkan kesejahteraan masyarakat melalui penyaluran dana bergulir. Perbaikan kondisi social ekonomi ini merupakan dampak turunan dari peningkatan kinerja usaha produktif yang di jalankan oleh masyarakat.

\section{Tujuan dan Sasaran Pinjaman Bergulir}

Pinjaman bergulir adalah pinjaman yang diberikan kepada masyarakat miskin melalui Kelompok Swadaya Masyarakat (KSM), untuk meningkatkan pendapatan dan kesejahteraannya. Sedangkan Tujuan pinjaman bergulir adalah untuk menyediakan akses layanan keuangan kepada rumah tangga miskin dengan berbasis mikro atau berbasis pasar dengan kegiatan yang menghasilkan pendapatan yang biasanya tidak memilki akses ke sumber pinjaman lainnya, untuk memperbaiki kondisi ekonomi mereka dan kegiatan yang mendukung tumbuhnya ekonomi serta usaha mikro, disamping itu membelajarkan mereka dalam hal mengelola pinjaman dan menggunakannya secara benar. Sasaran pinjaman bergulir adalah rumah tangga miskin diwilayah desa/kelurahan dimana BKM berada, khususnya warga miskin yang sudah tercantum dalam daftar warga miskin. ${ }^{5}$

\section{Pengertian Pemberdayaan}

Secara etimologi Pemberdayaan berasal dari kata "daya" yang berarti kemampuan untuk melakukan sesuatu. ${ }^{6}$ Sedangkan dalam bahasa Inggris Pemberdayaan berasal dari kata "empowerment", yang secara harfiah bisa diartikan sebagai "pemberkuasaan", dalam arti pemberian atau peningkatan "kekuasaan" (power) kepada masyarakat yang lemah atau tidak beruntung. ${ }^{7}$ Istilah pemberdayaan juga dapat diartikan sebagai upaya memenuhi keinginan yang diinginkan oleh individu, kelompok dan masyarakat luas agar mereka memiliki kemampuan untuk melakukan pilihan.Pemberdayaan dapat dimaknai sebagai suatu proses menuju berdaya, proses memperoleh daya, atau proses

5 Kememntrian Pekerjaan Umum, Program Nasional Pemberdayaan Masyarakat, (Direktorat Jenderal Cipta Karya), hal. 55-57.

${ }^{6}$ W.J.S. Poerwadarminta, Kamus umum Bahasa Indonesia, (Jakarta: Balai Pustaka, cet VIII,1996), hal. 233.

7 Abu Huraerah, Pengorganisasian dan Pengembangan Masyarakat, (Bandung: Humaniora, 2011), hal. 96. 
pemberian daya dari pihak yang memiliki daya kepada pihak yang kurang atau belum berdaya. ${ }^{8}$

Ada beberapa pendapat para ahli mengenai pengertian pemberdayaan, anatara lain

a. William Webster, Empowerment memiliki dua arti, pertama berarti to give power or authority to, yaitu memberikan kekuasaan atau kekuatan pada pihak lain. Kedua, to give ability or enable yaitu upaya untuk memberi kemapuan atau keberdayaan. ${ }^{9}$

b. Gunawan Sumodiningrat, pemberdayaan adalah pemberian energy agar rakyat mampu bergerak secara mandiri, sehingga dengan demikian pemberdayaan tidaklah bersifat selamanya, melainkan sampai targrt mampu mandiri dan kemudian dilepas untuk mandiri, akan tetapi dari jauh tetap diamati dan terus dijaga agar tidak jatuh lagi. ${ }^{10}$

c. Rappaport, pemberdayaan adalah cara agar rakyat, komunitas, dan organisasi diarahkan agar mampu menguasai atau berkuasa atas kehidupannya. ${ }^{11}$

d. Esrom Aritonang, pemberdayaan sebagai usaha untuk mengembangkan kekuatan atau kemampuan (daya), potensi sumber daya masyarakat. ${ }^{12}$

e. Koesnadi Hardjasoemantri, pemberdayaan adalah upaya sadar dan berencana menggunakan atau mengelola sumber daya secara bijaksana dalam pembangunan dan meningkatkan mutu hidup. ${ }^{13}$

f. Menurut Jim Ife, Pemberdayaan berarti memberikan sumberdaya, kesempatan, pengetahuan dan keterampilan kepada warga untuk meningkatkan kemampuan mereka dalam menentukan masa depannya sendiri dan berpartisipasi dalam dan memengaruhi kehidupan dari masyarakatnya. ${ }^{14}$ Pendapat Jim Ife tersebut, ada empat item penting yang harus diperhatikan dalam program pemberdayaan, yaitu menyiapkan sumber daya, pengetahuan, kesempatan dan keterampilan. ${ }^{15}$

g. World Bank, pemberdayaan berarti sebagai upaya untuk memberikan kesempatan dan kemampuan kepada kelompok masyarakat (miskin) untuk mampu dan berani bersuaraatau menyuarakan pendapat, ide, atau gagasan-gagasannya, serta kemampuan dan keberanian untuk memilih sesuatu (konsep, metode, produk, tindakan, dll) yang terbaikbagi pribadi, keluarga dan masyarakatnya. Dengan kata

8 Sulistiyani dan Ambar Teguh, Kemitraan dan Model-Model Pemberdayaan, (Yogyakarta: Gava Media, 2004), hal. 10.

9 Ony S Prijono, Pemberdayaan Konsep Kebijakan dan Implementasi, (Jakarta: CSIS, 1996), hal. 3.

${ }_{10}$ Chabib Soleh, Dialetika Pembanunan dengan Pemberdayaan, (Bandung: Fokus Media, 2014), hal. 17

11 Totok Mardikanto dan Poerwoko Soebianto, Pemberdayaan Masyarakat Dalam Perspektif Kebijakan Publik, (Bandung: Alfabeta,2013), hal 28

12 Esrom Aritonang dkk, Pendamping Komunitas Pedesaan, (Jakarta : Sekretariat Bina Desa,2001), hal.9.

13 Koesnadi Hardjasoemantri, Pemberdayaan Masyarakat Berwawasan Lingkungan sebuah pendekatan hokum lingkungan dalam Muhammadiyah dan pemberdayaan rakyat, (Yogyakarta: Pustaka Pelajar, 1995), hal. 61.

14 Jim Ife, "Community Development: Creating Community Alternative-Vision, Analysis and Practice", dalam Tatan Hermansah, dkk, Dasar-dasar Pengembangan Masyarakat Islam (Jakarta: Fakultas IImu Dakwah dan Komunikasi UIN Syarif Hidayatullah, 2009), hal. 29

${ }^{15}$ Icol Dianto, "PEMBERDAYAAN KELOMPOK USAHA PENINGKATAN PENDAPATAN KELUARGA SEJAHTERA (UPPKS) DALAM MENINGKATKAN KESEJAHTERAAN KELUARGA DI PASAMAN," Jurnal Hikmah 10, no. 1 (2016), hlm. 124. 
lain, pemberdayaan masyarakat merupakan proses meningkatkan kemampuan dan sikap kemandirian masyarakat. ${ }^{16}$

Dijelaskan pula dalam Al-Qur'an suroh Ar-Ra'd ayat 11 yang berbunyi :

"Bagi manusia ada malaikat-malaikat yang selalu mengikutinya bergiliran, di muka dan di belakangnya, mereka menjaganya atas perintah Allah. Sesungguhnya Allah tidak merobah Keadaan sesuatu kaum sehingga mereka merobah keadaan yang ada pada diri mereka sendiri. dan apabila Allah menghendaki keburukan terhadap sesuatu kaum, Maka tak ada yang dapat menolaknya; dan sekali-kali tak ada pelindung bagi mereka selain Dia".

Berdasarkan ayat ini dijelaskan bahwa Allah tidak akan megubah nasib suatu kaum sampai mereka mengubah keadaan diri mereka sendiri. Kaitan ayat ini dengan pemberdayaan adalah setiap individu diajarkan untuk mandiri dan berusaha dalam memenuhi kebutuhannya sebab jika kita tidak berusaha maka Allah swt tidak akan membantu setiap hamba yang bermalas-malasan dan hanya berpangku tangan menerima segalanya. Masyarakat adalah sekumpulan atau sejumlah besar orang yang menyatu dan menempati wilayah tertentu. ${ }^{17}$ Defenisi lain mengatakan masyarakat merupakan kelompok manusia yang saling terkait dan terikat oleh sistem-sistem, adat-istiadat, dan hukum - hukum tertentu. ${ }^{18} \mathrm{Jadi}$, Pemberdayaan masyarakat adalah upaya untuk menciptakan atau meningkatkan kapasitas masyarakat, baik secara individu maupun kelompok, dalam memecahkan berbagai persoalan terkait upaya peningkatan kualitas hidup, kemandirian dan kesejahteraan.Adapun makna pemberdayaan masyarakat yang dimaksud dalam penelitian ini, yaitu upaya partisipasi bersama secara terprogram, terarah, terorganisir untuk meningkatkan harkat dan martabat golongan masyarakat yang sedang dalam kondisi kurang sejahtera sampai miskin, sehinggga mereka dapat melepaskan diri dari perangkap kemiskinan dan keterbelakangan. Dalam konsep pemberdayaan, menurut Prijono dan dan Pranarka, manusia adalah subjek dari dirinya sendiri. ${ }^{19}$ Proses pemberdayaan yang menekankan pada proses memberikan kemampuan kepada masyarakat agar menjadi berdaya, mendorong atau memotivasi individu agar mempunyai kemampuan atau keberdayaan untuk menentukan pilihan hidupnya.

\section{Pembahasan}

1. Kinerja Tim PNPM Dalam Penyaluran Dana Ekonomi Bergulir

a. Sosialisasi Kinerja Tim PNPM

Sosialisasi adalah suatu proses penanaman atau transfer kebiasaan atau nilai dan aturan dari satu generasi lainnya dalam sebuah kelompok atau masyarakat. Dalam penyaluran dana ekonomi bergulir terlebih dahulu dilakukan dengan cara sosialisasi. Dalam penyaluran ekonomi bergulir di kelurahan Padangmatinggi dilakukan oleh Tim PNPM dan UPK. UPK diangkat oleh tim PNPM dan masyarakat, yang berperan dalam menyelesaikan segala urusan keuangan, baik itu dari segi penyaluran sampai pengumpulan dana kembali dari masyarakat.

\footnotetext{
${ }^{16}$ Aprillia Theresia, dkk., Pembangunan Berbasis Masyarakat, (Bandung: Alfabeta, 2014), hal. 11

${ }_{17}$ Kamarul Zaman, Kamus IImiah Serapan, (Yogyakarta: Absolute, 2005).

18 Tilar, Pendidikan Kebudayaan dan Masyarakat Madani Indonesia, (Bandung: Rosda Karya, 1999), hal. 9.

${ }_{19}$ Totok Mardikanto dan Poerwoko Soebiato, Pemberdayaan Masyarakat Dalam Perspektif Kebijakan Publik, (Bandung: Alfabeta, 2013), hal. 47.
} 
Berdasarkan hasil observasi bahwa teknik yang digunakan oleh BKM/KSM dalam sosialisasi yaitu dengan musyawarah maupun rapat. Karena sebelum mengadakan evaluasi BKM/KSM sudah memberitahu kepada masyarakat terlebih dahulu sebelum dilakukan sosialisasi. ${ }^{20}$

Hasil ini didukung dengan hasil wawancara dengan Zein sekretaris BKM/KSM kelurahan Padangmatinggi mengatakan bahwa kami akan mengumukan ke masyarakat, bahwa sosialisasi mengenai dana ekonomi bergulir akan dilaksanakn. Jadi pihak PNPM dan BKM/KSM hanya menunggu masyarakat ditempat yang sudah disepakati. ${ }^{21}$

Berdasarkan hasil observasi bahwa sosialisasi diadakan sebelum masyarakat menerima bantuan dana ekonomi bergulir dan di mulai pukul 20.00 Wib - selesai. Sosialisasi ini dilakukan untuk mempermudah dan mempercepat pihak PNPM menerima data-data masyarakat yang layak mendapatkan bantuan dana ekonomi bergulir di kelurahan Padangmatinggi. ${ }^{22}$

b. Pemetaan Rumah Tangga Miskin (RTM)

Pemetaan adalah suatu proses pengukuran, perhitungan, dan gambaran dengan menggunakan cara atau metode tertentu. Dalam pemetaan RTM ini terlebih dahulu dilakukan dengan cara mengelompokkan RTM. Pemetaan RTM dilaksanakan oleh $\mathrm{BKM} / \mathrm{KSM}$ kelurahan Padangmatinggi. BKM/KSM diangkat oleh PNPM dan masyarakat, yang berperan dalam menyelesaikan segala urusan, baik dari segi survey rumah layak huni sampai dengan pengelompokkan RTM.

Berdasarkan hasil observasi di kelurahan Padangmatinggi bahwa teknik yang digunakan oleh $\mathrm{BKM} / \mathrm{KSM}$ dalam pemetaan RTM yaitu turun langsung kelapangan dengan cara door to door, untuk mendapatkan data yang akurat dalam memetakan rumah tangga miskin di kelurahan Padangmatinggi. ${ }^{23}$

Berdasarkan hasil wawancara dengan Tim PNPM yaitu dengan Bintang mengatakan sebelum dipetakan maupun dikelompokkan ke RTM, pihak BKM/KSM akan memilih mana rumah yang layak huni dan tidak layak huni. Sehingga dapat diklasifikasikan dan dikelompokkan kedalam rumah tangga miskin yang nantinya dapat menerima bantuan. ${ }^{24}$

Begitu juga dengan pernyataan Siti Aminah salah satu masyarakat di kelurahan Padangmatinggi mengatakan bahwa pengelompokkan RTM ini sangat membantu bagi kami yang tergolong masyarakat miskin. Sebab adanya pemetaan ini kami tidak merasa khawatir untuk tidak mendapatkan bantuan untuk masyarakat miskin. ${ }^{25}$

Berdasarkan hasil wawancara dengan sekretaris BKM/KSM, Zein mengatakn pengelompokkan RTM ini tidak selalu berjalan dengan lancar, ada juga masalah dan kendala yang kami rasakan saat turun kelapangan untuk mensurvei secara langsung kondisi masyarakat itu sendiri. Masalah yang kami hadapi dilapangan yaitu masalah masyarakat yang terkadang bersikeras ingin ikut pinjaman dana ekonomi bergulir padahal dari segi ekonomi mencukupi, dan sebaliknya masyarakat miskin ingin mendapatkan pinjaman dana ekonomi bergulir tetapi tidak memiliki usaha ini juga tiak

${ }^{20}$ Observasi di Kelurahan Padangmatinggi, Rabu 28 Februari 2018.

21 Zein, Sekretaris BKM/KSM di Keluarahan Padangmatinggi, Wawancara Minggu 11 Maret 2018.

${ }^{22}$ Observasi di Kelurahan Padangmatinggi, Kamis 1 Maret 2018.

23 Observasi di Kelurahan Padangmatinggi, Rabu 28 Februari 2018.

24 Bintang, Tim PNPM di Kelurahan Padangmatinggi, Wawancara, Sabtu 28 Juli 2018.

${ }^{25}$ Siti Aminah, Masyarakat di Kelurahan Padangmatinggi, Wawancara, Sabtu 10 Maret 2018. 
bisa mendapatkan pinjman dana ekonomi bergulir, dan kendala yang kami alami saat turun langsung ke lapangan faktor cuaca yang terkadang tidak bersahabat. ${ }^{26}$

2. Penyaluran Dana Ekonomi Bergulir di Kelurahan Padangmatinggi

Berdasarkan hasil observasi yang telah dilakukan di kelurahan Paadangmatinggi tentang penyaluran dana ekonomi bergulir, disalurkan kepada masyarakat miskin yang sudah memenuhi kriteria peminjaman dana ekonomi bergulir. Jumlah yang menerima bantuan dana ekonomi bergulir dari tahun 2008-2014 sebanyak 30 kelompok. Berdasarkan hasil observasi yang telah dilakukan peneliti, masyarakat yang menerima bantuan dana ekonomi bergulir harus memiliki usaha dan kelompok. Dalam satu kelompok terdiri dari 4,5,6,7 orang, yang masing-masing orang mendapat pinjaman sebesar Rp.500.000,-. Tetapi tidak semua masyarakat miskin mendapat bantuan pinjaman dana ekonomi bergulir, dikarenakan tidak adanya persetujuan keluarga (kepala keluarga) dan tidak memiliki usaha. ${ }^{27}$

Seperti hasil wawancara dengan sekretaris BKM/KSM, Zein mengatakan bahwa pada tahun 2008 dana ekonomi bergulir diberikan kepada masyarakat miskin sebesar Rp.500.000,-/orang yang dicicil selama 10 bulan dengan jasa Rp.62.500,-/orang. Jasa yang kami terima dari masyarakat dikelola oleh UPK untuk hal-hal yang positif seperti memberikan bantuan kepada panti asuhan, anak yatim, panti jompo, dan lain sebagainya. $^{28}$

Begitu juga dengan hasil wawancara dengan tim dengan Khoiri, mengatakan dengan adanya penyaluran dana ekonomi bergulir dapat menambah modal masyarakat dalam mengembangkan usaha yang di miliki. Meskipun pinjaman yang diberikan tidak terlalu besar hanya Rp.500.000,-.. ${ }^{29}$

Salmina masyarakat kelurahan Padangmatinggi mengungkapkan, BKM/KSM dan UPK menyalurkan bantuan dana ekonomi bergulir kepada orang-orang yang memang betul- betul membutuhkan dan mereka sudah tahu bagaimana kondisi penerima bantuan dana ekonomi bergulir. Proses pengembalian pinjaman dana ekonomi bergulir ini tidak terlalu memberatkan kami, karena dengan jangka waktu 10 bulan untuk mengembalikan pinjaman tersebut dengan jasa Rp.62.500,-. ${ }^{30}$

Wawancara dengan salah satu pengurus BKM/KSM yaitu dengan Ovvy, mengatakan bahwa orang-orang yang menerima bantuan dana ekonomi bergulir berasal dari golongan orang yang tidak mampu, yang bertujuan untuk memberdayakan ekonomi masyarakat miskin. Penyaluran dan pengembalian ini berjalan dengan baik dan masyarakat yang menerima bantuan dana ekonomi bergulir merasa terbantu dari segi ekonomi.

Pada tahun 2013 kelurahan Padangmatinggi mendapat dana Reword sebesar Rp.100.000.000,- karena termasuk kelurahan terbaik dalam proses penyicilan pinjaman. Dana ini masuk ke rekening BKM dan dikelola oleh UPK untuk disalurkan kembali kepada masyarakat miskin. Jumlah kelompok yang menerima bantaun reword sebanyak 8 kelompok yang terdiri dari 4,5,6 orang dalam satu kelompok. 1 orang

${ }^{26}$ Zein, Sekretaris BKM/KSM di Keluarahan Padangmatinggi, Wawancara Minggu 11 Maret 2018.

${ }_{27}^{27}$ Observasi di Kelurahan Padangmatinggi, Selasa 6 Maret 2018.

${ }^{28}$ Zein, Sekretaris BKM/KSM di Keluarahan Padangmatinggi, Wawancara Senin 5 Maret 2018.

${ }^{29}$ Khoiri, tim PNPM di Kelurahan Padangmatinggi, Wawancara, Senin 30 Juli 2018.

${ }^{30}$ Ovvy, UPK di Kelurahan Padangmatinggi, Minggu 11 Maret 2018. 
mendapat pinjaman sebesar Rp.2.000.000,- dengan jangka waktu pengembalian selama 20 bulan. $^{31}$

Sementara wawancara dengan salah satu masyarakat di kelurahan Padangmatinggi yaitu dengan Rikhatson mengatakan bahwa orang-orang yang menerima bantuan dana reword ini adalah pinjaman yang sudah melakukan peminjaman sebelumnya dan diakui oleh BKM kebagusan proses pembayaran cicilan pinjamnya. Dan pinjaman dana reword ini sangat membantu kami dalam mengembangkan usaha dan menambah pendapatan kami. Sehingga dengan adanya bantuan dana ekonomi bergulir sudah tepat sasaran karena masyarakat yang menerima bantuan dana ekonomi bergulir berasal dari kalangan kurang mampu. ${ }^{32}$

Dana yang diberikan PNPM sudah dikembalikan masyarakat yang meminjam bantuan dana ekonomi bergulir, tetapi dana reword yang disalurkan kepada masyarakat masih ada yang belum dikembalikan sebesar Rp.60.000.000,-.

Alasan masyarakat tidak membayar cicilan dana reword anatara lain sebagai berikut :

1) Masyarakat menganggap dana reword adalah dan gibah,

2) Bangkrut,

3) Pindah,

4) Tidak ada tindak lanjut yang serius dari tim PNPM maupun UPK sehingga masyarakat tidak membayar cicilan.

Berdasarkan hasil observasi dan wawancara dari masyarakat dan BKM kelurahan Padangmatinggi dapat di evaluasi, karena banyaknya masalah penyicilan pinjaman dana ekonomi bergulir yang tidak dibayar kembali oleh masyarakat yang meminjam bantuan ekonomi bergulir. PNPM memberhentikan penyaluran dana ekonomi bergulir kepada masyarakat kelurahan Padangmatinggi.

Dari beberapa masyarakat yang meminjam dana ekonomi bergulir ini, tidak semua usaha mereka berkembang dan berjalan dengan baik. Ada yang gagal (bangkrut) ada juga yang semakin berkembang. Misalnya saja ibu Paita yang meminjam dana ekonomi bergulir untuk berjualan kerupuk opak bukannya semakin berkembang tetapi semakin mengalami kebangkrutan akibat kurangnya pelayanan prima maupun kualitas jualan itu sendiri sehingga ibu paita tidak bisa membayar cicilan hutang. Lain dengan ibu siti aminah, dengan adanya bantuan dana ekonomi bergulir ini ibu siti aminah semakin giat berjualan dan kualitas makanan yang dijualpun sepadan dengan harga yang diberikan sehingga untuk tahun depan beliau tidak akan meminjam lagi dan sudah bisa berdiri dan mengembangkan usaha sendiri.

3. Tantangan dan Peluang dalam Penyaluran Dana Ekonomi Bergulir

Tantangan adalah suatu hal atau bentuk usaha yang memiliki tujuan untuk menggugah kemampuan. Peluang adalah kesempatan yang diberikan kepada masyarakat dalam mengembangkan usahanya. Berdasarkan hasil wawancara dari tim PNPM dan UPK yang menjadi indicator tantangan dan peluang dalam penyaluran dan ekonomi bergulir, yaitu :

a. Monitoring

Monitoring adalah aktivitas yang dilakukan untuk memberikan informasi dari sebab atau akibat yang sedang dilaksanakan. UPK memonitoring perkembangan usaha masyarakat 1 kali dalam 1 bulan. Berdasarkan pemonitoringan ini UPK melaporkan

${ }^{31}$ Ovvy, UPK di Kelurahan Padangmatinggi, Minggu 11 Maret 2018.

32 Rikhatson, Masyarakat di Kelurahan Padangmatinggi, Wawancara, Rabu 7 Maret 2018. 
semua keadaan dilapangan kepada Tim PNPM dan ketua BKM/KSM. Seperti hasil wawancara dengan salah satu pengurus BKM/KSM dengan Arifin mengatakan bahwa UPK memonitorig perkembangan usaha masyarakat yang menerima bantuan dana ekonomi bergulir secara langsung kepasar Saroha. Pemonitoringan ini dilaksanakan demi mendapatkan data dan fakta secara akaurat dar masyarakat dilapangan. ${ }^{33}$

Begitu juga dengan salah satu masyarakat di kelurahana Padangmatinggi dengan Ida, mengatakan UPK melakukan pemantauan atau pemonitorigan usaha kami secara langsung. ${ }^{34}$ Hairani mengatakan bahwa pemonitoringan usaha terus dilakukan 1 kali 1 bulan. UPK juga terus memantau perkembangan usaha yang dijalani, dari hasil pemonitoringan tersebut menjadi alasan utama dalam mencari solusi dalam perkembangan usaha agar lebih baik kedepannya. ${ }^{35}$ Wawancara dengan UPK yaitu dengan Ovvy mengatakan bahwa tantangan yang dirasakan dalam pemonitoringan usaha masyarakat yaitu kurangnya keterbukaan masyarakat kepada UPK dalam mengungkapkan kondisi usaha mereka, jika terjadi masalah maupun kendala dalam berwirausaha. Dan kendala yang dialami UPK dalam memonitoring usaha masyarakat yang meminjam dana ekonomi bergulir di kelurahan Padangmatinggi yaitu kendala cuaca yang tidak menentu. ${ }^{36}$

b. Pembinaan

Pembinaan adalah suatu usaha untuk memberikan pengarahan dan bimbingan guna untuk mencapai suatu tujuan tertentu. Tim PNPM juga melakukan pembinaan terhadap usaha-usaha masyarakat, setelah adanya pemonitoringan maka dilakukan pembinaan. Seperti hasil wawancara dengan sekretaris BKM/KSM dengan Zein mengatakan bahwa pembinaan perkembangan usaha masyarakat terus dilakukan. Hal ini dibuktikan dengan diadakannya rapat 1 kali dalam 1 bulan untuk membicarakan apa saja yang menjadi kendala sehingga usaha mereka tidak berkembang. ${ }^{37}$ Begitu juga dengan salah satu masyarakat kelurahan Padangmatinggi dengan Zasna mengatakan bahwa ketua BKM/KSM dan UPK terus memberikan pembinaan terhadap kami demi perkembangan usaha kami. Baik dari segi perekonomian untuk memberdayakan kami dari yang tidak berdaya menjadi berdaya. ${ }^{38}$

Tasmina mengatakan bahwa pembinaan usaha masyarakat terus dilakukan, berdasarkan pembinaan dari tim PNPM, BKM/KSM dan UPK, kami mendapat solusi terhadap kesulitan-kesulitan yang kami alami dalam perkembangan usaha. Adapun pembinaan yang dilakukan BKM/KSM yaitu mengemas makanan supaya menarik, mengajari masyarakat pemasaran dan pelayanan prima. ${ }^{39}$ Wawancara dengan Zein sekretaris BKM/KSM mengatakan bahwa tantangan yang dirasakan dalam membina usaha masyarakat yaitu sulitnya dalam mengumpulkan seluruh anggota masyarakat yang meminjam dana ekonomi bergulir. sehingga masyarakat yang ingin dibina dalam pengembangan usahanya tidak dapat memahami bagaimana sebenarnya strategi dan teknik pengembangan usaha mereka.

${ }^{33}$ Arifi, Pengurus BKM/KSM di Keluarahan Padangmatinggi, Wawancara Minggu 4 Maret 2018.

${ }^{34}$ Ida, Masyarakat di Kelurahan Padangmatinggi, Wawancara, Senin 5 Maret 2018.

${ }^{35}$ Hairani, Masyarakat di Kelurahan Padangmatinggi, Wawancara, Rabu 7 Maret 2018.

${ }^{36}$ Ovvy, UPK di Kelurahan Padangmatinggi, Minggu 11 Maret 2018.

37 Zein, Sekretaris BKM/KSM di Keluarahan Padangmatinggi, Wawancara Sabtu 10 Maret 2018.

${ }^{38}$ Zasna, Masyarakat di Kelurahan Padangmatinggi, Wawancara, Senin 5 Maret 2018. 2018.

39 Tasmina, Masyarakat di Kelurahan Padangmatinggi, Wawancara, Sabtu 10 Maret 
Peluang yang dirasakan BKM/KSM dalam membina masyarakat yaitu mudahnya masyarakat menerima masukan-masukan yang disampaikan kepada mereka dan tidak ada rasa malu dalam menjalani usaha mereka. ${ }^{40}$

c. Solusi

Solusi adalah jalan keluar atau jawaban dari suatu masalah. Tim PNPM dan $\mathrm{BKM} / \mathrm{KSM}$, UPK memberikan solusi maupun jalan keluar terhadap masyarakat yang memiliki masalah dalam perkembangan usaha. Solusi yang diberikan kepada masyarakat yang mengalami masalah dalam pengembangan usahanya yaitu :

1) Membuat kemasan makanan dengan seunik-uniknya,

2) Pemasaran dengan cara berkeliling, dan

3) Menggunakan media online (sosial).

Seperti hasil wawancara dengan sekretaris BKM/KSM dengan Zein mengatakan bahwa tim PNPM siap siaga dalam memberikan solusi terhadap masyarakat yang mngalami kendala atau masalah dalam perkembangan usaha. Berdasarkan masalah ini masyarakat dan BKM/KSM sama-sama mencari jalan keluar terhadap masalah yang sedang dialami. ${ }^{41}$ Begitu juga dengan salah satu masyarakat di kelurahan Padangmatinggi dengan Nurintan mengatakan bahwa tim PNPM, BKM/KSM, dan UPK selalu siap mendengar segala masalah yang kami alami. Berdasarkan itu ketua $\mathrm{BKM} / \mathrm{KSM}$ mengadakan rapat untuk penyelesaian masalah yang kami alami untuk pengembangan usaha. ${ }^{42}$ Asmawati mengungkapakn bahwa tim PNPM, BKM/KSM, dan UPK sangat terbuka dalam mendengar keluh kesah yang kami rasakan, mereka juga memberikan arahan-arahan dan masukan-masukan dengan setiap masalah yang kami alami dalam proses pengembangan usaha yang kami jalani. Solusi yang mereka berikan yaitu dengan membuat kemasan makanan. ${ }^{43}$

Wawancara dengan Ovvy yaitu UPK kelurahan Padangmatinggi mengatakan bahwa orang-orang yang memiliki masalah dalam perkembangan usahanya terus dibina dan diberikan solusi maupun jalan keluar yang dapat dijangkau oleh masyarakat itu sendiri. Salah satunya bisa dengan menggunakan atau memanfaatkan media sosial dalam memasarkan produk yang mereka jual demi mengurangi tingkat persaingan yang ada di pasar Saroha. ${ }^{44}$ Sementara dilain hari wawancara dengan masyarakat kelurahan Padangmatinggi yaitu dengan Mawarti bahwa tim PNPM dan BKM/KSM sangat terbuka dalam memberikan arahan dan solusi terhadap masalah yang kami alami dalam mengembangkan usaha yang kami jalani. Salah satunya dengan mengajarkan kami cara mengemas dan memasak makanan yang akan kami pasarkan dipasar Saroha. Berdasarkan ini kami dapat lebih semangat dalam menjualkan produk-produk kami, karena dukungan dari tim PNPM dan BKM/KSM kelurahan Padangmatinggi. ${ }^{45}$

Berdasarkan hasil observasi peneliti di kelurahan Padangmatinggi, seharusnya masyarakat harus lebih tepat janji dalam pengembalian pinjaman dana ekonomi bergulir sehingga tim PNPM dan UPK lebih baik dalam memberikan bantuan dana dalam

${ }^{40}$ Zein, Sekretaris BKM/KSM di Keluarahan Padangmatinggi, Wawancara Minggu 11 Maret 2018. Maret 2018.

${ }^{41}$ Zein, Sekretaris BKM/KSM di Keluarahan Padangmatinggi, Wawancara Minggu 11

${ }^{42}$ Nurintan, Masyarakat di Kelurahan Padangmatinggi, Wawancara, Senin 5 Maret 2018. 2018.

${ }^{43}$ Asmawati, Masyarakat di Kelurahan Padangmatinggi, Wawancara, Sabtu 10 Maret

${ }^{44}$ Ovvy, UPK di Kelurahan Padangmatinggi, Minggu 11 Maret 2018. 2018.

45 Asmawati, Masyarakat di Kelurahan Padangmatinggi, Wawancara, Rabu 7 Maret 
pengembangan usaha mereka. Masyarakat juga harus bisa memberikan hal-hal yang baru ataupun unik dalam mendukung kemasan mereka dalam menghadapi persaingan dipasar Saroha.

\section{Kesimpulan}

Berdasarkan hasil penelitian yang telah dilakukan oleh peneliti terhadap Evaluasi Terhadap Kinerja Tim PNPM Dalam Penyaluran Dana Ekonomi Bergulir Untuk Memberdayakan Masyarakat di Kelurahan Padangmatinggi, maka dapat disimpulkan sebagai berikut:

1. Kinerja PNPM dalam penyaluran dana ekonomi bergulir untuk memberdayakan masyarakat dikatakan tidak berjalan dengan baik. Karena jika dilihat dari indicator kinerja tim PNPM (mensurvei, mendata, penyaluran, pengawasan, dan evaluasi) tersebut, ada diantaranya yang tidak berjalan dengan baik yaitu tentang pengawasan. Karena kurangnya pengawasan atau pemantauan dari tim PNPM dan UPK tidak semua masyarakat yang meminjam bantuan dana ekonomi bergulir mengembalikan pinjamnnya.

2. Penyaluran dana ekonoi bergulir dapat memberdayakan masyarakat. Tidak semua masyarakat dapat diperdayakan, karena jika dilihat dari ketiga indicator pemberdayaan masyarakat (mampu memenuhi kebutuhan pokok, mampu meningkatkan taraf hidup, dan meningkatkan pendapatan ekonomi) tersebut, ada diantaranya yang tidak berjalan dengan baik yaitu tentang meningkatkan pendapatan ekonomi. Karena masih adanya masyarakat yang tidak mampu membayar tunggakan atau cicilan pinjaman dana ekonomi bergulir, sehingga masyarakat kurang berdaya.

3. Tantangan dan peluang dalam penyaluran dana ekonomi bergulir. UPK memiliki tantangan tersendiri dalam pengumpulan dana ekonomi bergulir yang dipinjam masyarakat. Salah satunya yaitu masyarakat yang terkadang menunggak dalam membayar cicilan dana ekonomi masyarakat, menjadi satu kendala yang membuat UPK harus bekerja keras untuk mengutip kembali dana-dana yang diberikan kepada masyarakat. Peluang adalah masyarakat merespon dengan baik dari PNPM dalam memberikan bantuan dana ekonomi bergulir. Sehingga UPK lebih mudah dalam menyalurkan bantuan dana ekonomi bergulir ke masyarakat.

\section{DAFTAR PUSTAKA}

Abu Huraerah, Pengorganisasian dan Pengembangan Masyarakat, Bandung:

Humaniora, 2011.

Ahmad Nizar, Metode Penelitian Pendidikan, Bandung: Cipta Pustaka Media, 2014.

Aprillia Theresia, dkk., Pembangunan Berbasis Masyarakat, Bandung: Alfabeta, 2014.

Chabib Soleh, Dialetika Pembanunan dengan Pemberdayaan, Bandung: Fokus media, 2014.

Dedy Mulyana, Metodelogi Penelitian Kualitatif, Bandung: Remaja Rosdakarya, 2009.

Esrom Aritonang dkk, Pendamping Komunitas Pedesaan, Jakarta: Sekretariat Bina Desa, 2001.

Hadari Nawawi, Manajemen Sumber Daya Manusia, Yogyakarta: PT Gajah Mada Press, 1997. 
https://id.m.wikipedia.org/wiki/PNPM_Mandiri_Pedesaan, diakses Senin pada 02 Februari 2018, Jam. 21:34 WIB.

Dianto, Icol. "PEMBERDAYAAN KELOMPOK USAHA PENINGKATAN PENDAPATAN KELUARGA SEJAHTERA (UPPKS) DALAM MENINGKATKAN KESEJAHTERAAN KELUARGA DI PASAMAN.” Jurnal Hikmah 10, no. 1 (2016): 122.

—. "PERANAN DAKWAH DALAM PROSES PENGEMBANGAN MASYARAKAT ISLAM.” Jurnal Hikmah 12, no. 1 (2018): 93.

Hurairah, Abu. Pengorganisasian Dan Pengembangan Masyarakat. Bandung: Humaniora, 2011.

Jim Ife, "Community Development: Creating community Alternative-vision, analysis and practice", dalam Tatan Hermansah, dkk, Dasar-dasar Pengembangan Masyarakat Islam. Jakarta: Fakultas Ilmu Dakwah dan Komunikasi UIN Syarif Hidayatullah, 2009.

Kamarul Zaman, Kamus Ilmiah Serapan, Yogyakarta: Absolute, 2005.

Kementrian Pekerjaan Umum, Program Nasional Pemberdayaan Masyarakat, (Direktorat Jenderal Cipta Karya).

Koesnadi Hardjasoemantri, Pemberdayaan Masyarakat Berwawasan Lingkungan sebuah pendekatan hukum lingkungan dalam Muhammadiyah dan pemberdayaan rakyat, Yogyakarta: Pustaka Pelajar, 1995.

Lexy J. Moleong, Metodologi Penelitian Kualitatif, Bandung: Remaja Rosdakarya, 2000.

Mardalis, Metode Penelitian Suatu Pendekatan Proposal, Jakarta: Bumi Aksara, 2003. Moh. Nazir, Metode Penelitian, Bogor: Ghalia Indonesia, 2005.

Ony S Prijono, Pemberdayaan Konsep Kebijakan Dan Implementasi, Jakarta: CSIS, 1996.

Sugiono, Metode Penelitian Pendidikan: Pendekatan Kuantitatif, Kualitatif dan R\&D, Bandung: Alfabeta, 2012.

Sugiyono, Metodelogi Penelitian Kuantitatif Kualitatif, Bandung: Alfabeta,2001.

Sulistiyani dan Ambar Teguh, Kemitraan dan Model-Model Pemberdayaan, Yogyakarta: Gava Media, 2004.

Tilar, Pendidikan Kebudayaan dan Masyarakat Madani Indonesia, Bandung: Rosda Karya, 1999.

Totok Mardikanto dan Poerwoko dan Soebianto, Pemberdayaan Masyarakat Dalam Perspektif Kebijakan Publik, Bandung: Alfabeta, 2013.

W.J.S. Poerwadarminta, Kamus umum Bahasa Indonesia, Jakarta: Balai Pustaka, cet VIII, 1996.

Zainil Arifin, Penelitian Pendidikan dan Pradigma Baru, Bandung: Rosdakarya, 2011. 